\title{
Legitimation through nationalism in the Ceauseșcu regime
}

\author{
Andrei Ghimisi ${ }^{1}$ \\ ${ }^{1}$ National University of Political Studies and Public Administration, Romania \\ E-mail: ghimisi4567@gmail.com
}

\begin{abstract}
The paper wishes to examine how did Nicolae Ceausescu legitimate himself in power during his rule as the leader of Romania between the years 1965-1989. One of the most important aspects is regarding Ceausescu and his cult, which will develop over the years, going from 1968 and his refusal to invade Czechoslovakia to his visits in North Korea and China where he saw firsthand the full extent of such a concept, the leader and his persona will always evolve until 1989. Other methods were also used by the leader to legitimate himself in the eyes of the Romanian people as the one true leader
\end{abstract}

Keywords: nationalism, cult, Ceausescu

\section{Introduction}

Nationalism is an ideology based on the fact that the individual's loyalty and devotion to the nation-state surpasses other individual or group interests. The movement is a modern one even though many believe because of its dynamic vitality and all-pervading character that is very old. Actually, the French and American revolutions may be regarded as its first powerful manifestations. After being introduced in the new countries of Latin America, it spread from there to Central Europe and after that, in the middle of the $19^{\text {th }}$ century, in east and southeast of Europe. In the beginning of the $20^{\text {th }}$ century nationalism began to have its grasp felt even in Africa and Asia.

If we are to translate the term "nationalism" into world politics, we can see that the term implies the identification of the people with the nation state. Hans Kohn in his article presents us how nationalism was defined within the state: "In the age of nationalism, but only in the age of nationalism, the principle was generally recognized that each nationality should form a state — its state — and that the state should include all members of that nationality".

Going even further into the evolution of states and nationalism we can see that the nation state did not exist during a very long time and history and actually it was not even regarded as an idea. "In the first 15 centuries of the Christian Era, the ideal was the universal world-state, not loyalty to any separate political entity" says Hans Kohn. He goes even further and presents us in his article that as a political allegiance "During the Middle Ages civilization was looked upon as determined religiously; for all the different nationalities of Christendom as well as for those of Islam there was but one civilizationChristian or Muslim - and but one language of culture - Latin (or Greek) or Arabic (or Persian)".

\section{Ceausescu and the leader cult (Consolidation of power 1965-1969. Elements creating the leader cult)}

Like in any totalitarian regime the cult obtained in the Ceausescu period a significant role in the official propaganda of the regime. But in the case of Ceausescu, this had important nationalism elements which offered it specific features. In the case of the Romania dictator, everything was giant, majestic. Romania 
is an important country on the international level, led by a genius ("The Danube of Thinking" was just one of the metaphors that were attributed to Ceausescu). The national history was dominated by important figures: Burebista, Decebal, Traian, Mircea cel Batran, Stefan cel Mare, Mihai Viteazul, A. I. Cuza, and the list finishing off with, of course, Nicolae Ceausescu.

Anneli Ute Gabanyi analyzes the role of placing the leader in the gallery described as "the great heroes of the nation" in the leader cult. The author presents the way in which a painting by Florin Ionescu became famous, the painting in which Ceausescu appeared last in a series of great leaders: Burebista, Decebal, Stefan cel Mare, Mihai Viteazul, Nicolae Balcescu, A. I. Cuza. The leaders were not picked randomly, Ceausescu wanting to be considered as an avatar of virtues, virtues now raised on a higher level- the communist one. Also the author explains the way in which the national propaganda became crucial in supporting the leader's personality cult, the appeal to history being frequently remembered. For example, in the symbolic correspondences that appeared in the Romanian press, you could see the coincidence regarding the birth year of the leader (1918) and the year of the Great Union, or the one regarding the month in which he was born and the month in which the unification of the Principalities had taken place (January). The appeal to history as a method of supporting the leader cult was also analyzed by Ramona Bordei, who considered that the dictatorship of Ceausescu supported a national propaganda in which Latinity, accompanied by other propaganda specific formulations, supported the cult of personality ${ }^{1}$.

On the other hand, Lucian Boia analyzes "the role of the official communist mythology" regarding the promoting of the leader cult, considering that national mythology was used in the benefit of the regime and dictator ${ }^{2}$. The author considers that the official propaganda promoted the idea that the Romanian nation had found in Ceausescu a crucial leader and because of this he needed to be listen to, and the relationship with the outside world should be eliminated. Regarding the cult of personality, Lucian Boia presents us that the official speech was promoting the contrast between the virtues of the Romanian nation (in which Ceausescu was the living embodiment of these virtues) and the negative effects of the foreign interventions. In this way, in order to eliminated the danger of "sickening" because of the contact with foreigners, Romania must be an independent and autonomic state. This Romania was dreamed by Ceausescu as a big power, and he behaved as such: the leader of a first rank country, with a serious word to say in international relationships.

If we are to talk about the origins of Nicolae Ceausescu's cult we will see that the theoretical foundation of the cult within the Romanian communism constitutes a sensitive topic since in makes use of both typologies which are familiar to general concepts regarding the cult as well as nuances of nationalism endemic to the Romanian case.

One of the most important elements that stand at the root of Romania's case study is its mythology. Vladimir Tismaneanu traces the founding myths of the cult of Ceausescu to the Ninth Congress of the $\mathrm{RCP}^{3}$. In this sense, we are presented not only a general conceptualization of the leader's power, but also how it was institutionalized. Without the proper institutional framework that linked society, economy, culture and the nation to the leader's esoteric personal image, the leadership of Romania would not have resisted in the 1970's. If we are to say that Ceausescu's finest hour was the Congress of the Party in July 1965, the years that followed assured the consolidation of his rule. The year 1968 was the moment that created all institutional and political instruments for the leader to obtain the total power within the party, which he actually did by capitalizing on both the effectiveness of his closest group and on his personal schemes and maneuvers inside the party ${ }^{4}$.

When troops entered Czechoslovakia in 1968, Ceausescu's reaction was vehement and most important, public. A rally was held in Bucharest and the Romanian leader described the events as "a

\footnotetext{
${ }^{1}$ Anneli Ute Gabanyi, Cultul lui Ceauşescu, Iaşi, 2003, p. 30.

${ }^{2}$ Ramona Bordei-Boca, „Latinitatea - reper identitar român”, în Chantal Delsol, M. Maslowski, Joanna Nowicki, Mituri şi simboluri politice în Europa Centrală, Bucureşti, 2003, p. 451.

${ }^{3}$ Tismăneanu, Stalinism for All Seasons, 197.

${ }^{4}$ Fischer, Nicolae Ceaușescu, 161-8.
} 
great mistake and a grave danger to peace...a shameful moment in the history of the revolutionary movement"

The most important consequence after the events in August 1968 was the immediate increase in Ceausescu's popularity. His stand gained him the personal figure and stature which no amount of diplomatic or economic achievement could have gained him. As soon as the immediate shock of the Czechoslovakia movement was over, the Romanian leader returned to his usual tactics of compromise and maneuver rather that a confrontation with the Russians.

Ellen Fisher has a more structured point of view regarding the root of Ceausescu's cult. Although she claims that after 1969 (the Tenth Congress), in the five year until the Eleventh Party Congress in 1974, Ceausescu became the "omnipotent and omniscient rule of his country and the object of a leadership cult", she sustains that in 1969 the cult had not been yet developed. The dominance by Ceausecu of the Tenth Congress in 1969 was a symptom of total power, but it only full emerged in the 1974 Election as the First President of Romania 5 .

\section{The 1970's period: The total affirmation of the cult and Ceausescu's rise to glory}

In the first period of the 1970s, Nicolae Ceausescu was in the process of strengthening his position and power. Although he managed to obtain political power inside the party, he needed to be recognized as a supreme leader by the people. In this process the ley role was on 28 March 1974, a moment which had created the persona of Nicolae Ceausescu, the President of the People.

The responses inside the party and in the media to this event were massive. The people that were attending his election were ranged from high ranking officials of the Communist party, former members in the "illegalist movement" that were close to Nicolae Ceausescu, members of the State Council and members of the Central Committee. Also the list goes on and on naming academy members, foreign journalist, people of science as well as diplomatic figures.

The ceremony was one that presents us with some key elements that belong to the cult propaganda of the leader: a scepter being given to Ceausescu to symbolize power and to form a comparison with the "great leaders of Romanian history", the constant praises, acclamations and discourses that were meant to be flattering in nature. The ceremony was given extensive credit at every level in the Romanian society.

Some of the predisposing elements that triggered the cult of the leader can be seen as the political history if the communist regime and its decisions that had a great impact on the cultural life. The visit in North Korea and China in the beginning on the year 1971 by Nicolae Ceausescu is seen by some scholars as being one of the moments that triggered a response inside the environment of the leader that wanted to expand the ideological methods of control by the party and to reorganize the cultural life of the Romanian people according to the self-proclaimed definition of the Marxism-Leninism ${ }^{6}$. It is because of these visits that Ceausescu considered the Asian examples of applied Marxist theory are well shaped and this will lead to some changes within the Romanian communist state: the increasing presence of the party and its members, the stratification of the Romanian cultural scene in accordance with the ideological standards of interpretation ${ }^{7}$. These lead to the expansion of the leader and its role.

Regarding the aspects of the political infrastructure inside the regime, Vladimir Tismaneanu points out that until 1974, Ceausescu had not gain the full support of the secret police, but after the event it became one of the three most important elements in his cult. alongside with the Party and Ministry of Propaganda.

Another pattern in the conceptual interpretation of the thesis deals with the role of the communist press in construction different elements of the cult. Following the theory towards the particularities of

5 Ibid, 160.

${ }^{6}$ See Ion Mihai Pacepa, Red Horizonts: The True Story of Niocalae and Elena Ceausescu, Crimes, Lifestyle and Corruption (Washington DC: Regnery Gateway,1987) Chapter 1 and Anneli Ute Gabanyi, Cultul lui Ceausescu (Iasi Polirom ,2003), Chapter 1

${ }^{7}$ For more information, see the Theoretical framework as well as Mary Ellen Fischer, Nicolae Ceausescu: A study in political leadership (London: Lynne Riennner Publishers ,1987) 
the press in Romania, Emilia Sercan presents us with the important role that the press had in Communist Romania, as a double configuring agent and also as a link between the regime and its citizens, and the instrument of legitimacy as it was created by the political regime.

In her book, Fisher also traces the sources of Ceausescu' cult to three main important factors: his "independent foreign policy", "the leader's strategies for internal economic development" and his personality. In addition, she stresses that the nature of the Romanian society, in its endemic form, was receptive to such a cult and actually made it easier for Ceausescu to impose this forced relationship on the Romanian people

\section{Conclusion}

One of the most important elements that stand at the root of the Romanian leader and his cult of personality is the use of mythology and this is traced to beginning of the Ninth Congress of the Romanian Communist Party. At that meeting, the party developed the thesis of the ethnic and social homogenization of the nation of Romania, a moment which clearly defined the most important ideological options of Ceausescu.

Ceausescu's strength in 1965 was that he resorted to a combination of four political strategies: personnel manipulation, policy ambiguity and compromise within the new collective leadership, move towards the institutionalization of the political process both state and Party and participatory populism and reforms, direct appeal to the Romanian people through political mobilization techniques regarding nationalism.

Ceausescu's most successful populist appeal was to the nationalist feeling in Romania. He continued and intensified the measures of derussification of the early 1960's and began to rewrite his own personal Romanian history. His first efforts regarding this were to create a place for the party and other leftist movements in Romanian history, but the major cause of his success in managing to mobilize Romanian nationalism to support his personal rule was the position that he took regarding the Warsaw Pact invasion of Czechoslovakia in 1968.

The Tenth Party Congress in 1969 August was the final victory for Nicolae Ceausescu. Every speaker felt compelled to start and end any remarks by praising the leader Party and many referred to Ceausescu in every paragraph, crediting him with the economic growth and achievements after 1965. Ceausescu had become the unique and undisputed leader of state and Party and would soon be the foundation of all knowledge in Romania. Despite this he was not yet the object of a cult in 1969.

The leader and his cult had, at that moment in time, began its ascendance into the second half of the 1970 s, one that will only end with the social disasters of the 1980s. At the same time, "The 1974 Moment" had presented this change in the press, which began to promote on the cultivation of national values, most of them that were in congruence with the supreme leader. It was the result of a process that started in 1971, when Ceausescu's "mini-cultural revolution" changed the Party's orientation in society.

If we are to look as a whole, Ceausescu struggled at the beginning to obtain his legitimation but managed, step by step, to implement his plan using forms of nationalistic propaganda, elements of symbolism and mythology and the most important factor, creating a cult of personality or leader cult in order to obtain his full legitimation. In the beginning of the 1980's, Ceausescu achieved his personal goal, that to become the one true leader and the hero that Romania needed, through the methods and tools that he used to legitimize himself, especially using the people and their nationalistic believes.

\section{References}

[1] Anneli Ute Gabanyi, Cultul lui Ceauşescu, Iaşi, 2003.

[2] Ramona Bordei-Boca, „Latinitatea - reper identitar român”, în Chantal Delsol, M. Maslowski, Joanna Nowicki, Mituri şi simboluri politice în Europa Centrală, Bucureşti, 2003.

[3] Tismăneanu, Stalinism for All Seasons, 2003.

[4] Fischer, Nicolae Ceaușescu, 1989.

[5] Ion Mihai Pacepa, Red Horizonts: The True Story of Niocalae and Elena Ceausescu, Crimes, Lifestyle and Corruption (Washington DC: Regnery Gateway, 1987) 